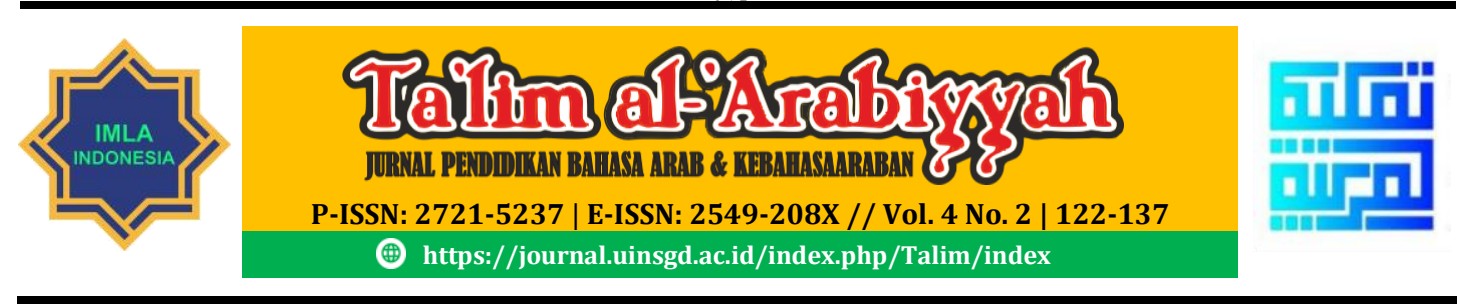

\title{
Arabic Learning Based On E-Learning Using Arabic Teacher Website In The Pandemic Era Of Covid-19
}

\author{
Nur Salsabila Binti Jasni ${ }^{1}$, Ade Arip Ardiansyah ${ }^{2}$ \\ ${ }^{1}$ University Of Malaya, Malaysia \\ ${ }^{2}$ UIN Sunan Gunung Djati Bandung, Indonesia \\ Corresponding E-mail: nursalsabila@um.edu.my
}

\begin{abstract}
This study aims to describe the Arabic Teacher's website as e-learning based Arabic language learning during the Covid-19 pandemic. The method used in this research is a descriptive qualitative method. There have been many studies that discuss learning Arabic based on E-Learning. However, it is only limited to one aspect while learning Arabic using the Arabic teacher website covers various skills and theoretical issues. The results showed 1) E-Learning Arabic Teacher is a complete website designed as an advanced learning Arabic during the Covid-19 pandemic; 2) The Arabic learning approach by using the Arabic teacher E-Learning website is based on the same teaching method programmed, develop internet-based independent learning effectively using a purposeful computer so that learners can learn Arabic in a balanced way read, write, listen, and speak. 3) E-Learning Arabic Teacher provides several main menus including; Arabic languages such as reading, stories (basic, intermediate, advanced), grammar (nabwu), structures (sentence patterns), dictation (imla), songs and games (songs and games), Questionnaires (assessment sheets) accompanied by an electronic book, MP3, and Video.
\end{abstract}

Keywords: Arabic Language Learning, Arabic Teacher, E-Learning, Website.

\section{ABSTRAK}

Penelitian ini bertujuan untuk mendeskripsikan website Arabic Teacher sebagai pembelajaran bahasa Arab berbasis e-learning di masa pandemi Covid-19. Adapun metode yang digunakan dalam penelitian ini adalah metode deskriptif-kualitatif. Telah banyak penelitian yang membahas mengenai pembelajaran Bahasa Arab berbasis E-Learning, namun hanya terbatas pada satu aspek saja sedangkan pembelajaran bahasa arab dengan menggunakan website Arabic Teacher mencakup berbagai aspek baik keterampilan maupun teoritis. Hasil penelitian menunjukan (1) E-Learning menggunakan website Arabic Teacher merupakan pembelajaran bahasa Arab berbasis E-Learning dengan metode pengajaran terprogram dimasa pandemi Covid-19; (2) E-Learning Arabic Teacher menyediakan beberapa main menu pembelajaran bahasa Arab seperti reading, stories (tingkat dasar, menengah, lanjut), grammar (nahwu), struktur (pola kalimat), imla', lagu dan permainan, lembar penilaian yang disertai dengan buku elektronik, MP3, dan Video.

Kata Kunci: Arabic Teacher, E-Learning, Pembelajaran Bahasa Arab, Website. 


\section{INTRODUCTION}

The development of information and communication technology (ICT) has entered education, thus demanding that education actors clean up (Saepudin, 2015). With computers in schools, test manuscripts, and exams usually written on the blackboard, typed manually has switched with using a computer (Ritonga et al., 2016). A scoring system and other administrative handling are also necessary computer-based according to ICT development (Ilmiani et al., 2020).

The development of information technology, especially communication developments, has at least 2 (two) technologies developing rapidly, first, cellular telephones (Iswanto, 2017). Second, Internet networked computers are computers used to connect people with other people without limitations on distance and time. Today's development of information and communication technology is developing a complex nature, where developments in technology are not only one-sided only in computer technology (CT). Still, it also accompanies it, the integration of the two fields of technology can influence all areas of community life, including education (Yasmar, 2017).

Along with the increasingly rapid development of information technology, there is a need for a concept and mechanism of technology-based teaching and learning becomes impossible avoided (Purwanto \& Hanief, 2016). The concept known as Elearning affects its occurrence the process of transforming education from conventional to digital form, both in terms of content and systems. The world community has widely accepted the concept of E-learning, as evidenced by the rampant implementation of E-learning in educational institutions(Martono Kurniawan \& Nurhayati Oky, 2014).

E-Learning is a modern learning system that utilizes computer technology (Silahuddin \& Azhari, 2019). In this case, Chang and Fang said that the characteristics of e-learning, among others. First, take advantage of electronic technology services. Second, using computers (digital media and computer networks). Third, using selflearning materials stored on a computer can be accessed by teachers and students anytime and anywhere if needed. Fourth, utilizing the learning schedule, curriculum, learning progress results, and matters relating to educational administration can be viewed at any time on the computer (Chang \& Fang, 2020). E-learning is an education system that uses electronic applications to support teaching and learning with internet media and computer networks (Pimada \& Muhammad Afif Amrulloh, 2020). Elearning essential criteria, namely; First, E-learning is networked, making it capable of improving fast, saving or retrieving, distributing, and sharing learning and information. Second, E-learning is sent to users via computer by using internet technology standards. Third, E-learning focuses on views learning as the most extensive learning solution that outperforms traditional training paradigms (Kurnia et al., 2018).

Rafiee \& Abbasian-Naghneh (Rafiee \& Abbasian-Naghneh, 2019) classifies the E-learning model into three: web courses, web-centric courses, and web-enhanced courses. The web course is the use of the internet to deliver material in distance learning. The web-centric course uses the internet to provide content via the internet in indoor education (Aziz Khoiri \& Fatkhu Romadhon, 2017). 
Meanwhile, the web-enhanced course is the use of the internet to support improving the quality of learning.

E-learning is also expected to provide the same advantages and benefits to the Arabic language learning process, especially Arabic Learning Design Planning (Azzuhri, 2015). The problem that has been faced by Arabic students and lecturers is the lack of learning material, which includes language skills (time, speaking, reading, and writing) and linguistic elements (mufradat, qaw $\bar{a}^{\prime} i d$, and $i m l a \vec{a}$ ) and other subjects, which are related to Arabic learning in the form of books, CDs. Arabic software tends to use old methods and techniques, namely, Teacher centered learning (Maryeni et al., 2020).

Along with the development of technology and communication today, many Arabic language learning based on E-learning has appeared on the internet by foreign language learning centers (Haffar et al., 2017). One of them is busuu.com. busuu.com website is an E-learning based foreign language learning. Suci Ramadhanti Febriani and Anasruddin state that Arabic four skills can be improved using technology in his research. In addition to integrated material, strategies, media, and adequate evaluation, students can learn Arabic. The various assignments can build a process of critical thinking, creative thinking, and students can learn independently in a broader context. And this study found that the impact of technology on students' language skills is when the constructivist approach can provide many opportunities and opportunities for students to be creative through the four Arabic language skills (Febriani \& Anasruddin, 2020).

Azkia Albantani, in his research entitled Optimizing The Busuu Application In Arabic Learning, states that this website is very relevant to use in foreign language learning, especially Arabic, because this website is supported by a team of native speakers or native speakers from 12 countries (English, French, German, Arabic, Dutch, Italian, Chinese, Japanese, Brazilian, Spanish, Russian and Turkish) and equipped with various learning features, namely; Lessons (Durüs), exercises (Tamärin), Vocabulary (Al-Mufradat) and Personal Notes (Shafhaty al-Syakhsyiah). Also, the subject matter is divided into five levels: Mubtadi' Beginner A1 (20 themes), Mubtadi' Beginners A2 (15 topics), Mutawassith - Intermediate B1 (14 items), Mutawassith Intermediate B2 (14 items), and Al-Dauraat al-Khasshah- Private Courses (5 themes) (Albantani, 2018).

Arabic in Malaysia is a foreign language subject taught in various educational institutions, both formal and non-formal. Arabic is shown at the elementary, junior high, and high school levels and universities in legal institutions. Meanwhile, in nonformal institutions, it is taught at Madrasah Diniyah and private foreign language institutions (Baharudin \& Ismail, 2014). Sahrir states that Arabic must be shown at the elementary, middle, and high school levels within the Ministry of Religion. Simultaneously, in the Ministry of National Education, Arabic is presented as a foreign language at the high school level. Meanwhile, Sahrir and Alias state that learning Arabic in Malaysia starts from the elementary level (elementary school) to higher education institutions, both public and private (Sahrir \& Alias, 2012). 


\section{METHOD}

This research uses a descriptive qualitative approach. The data is taken from the Arabic Teacher E-Learning page related to all information, features, teaching materials, etc., displayed by www.arabic-teacher.com. The collection technique used is an in-depth observation by browsing the website page to find out all the main menus, materials, and systematics. Meanwhile, data analysis used includes analyzing website content, data presentation, and concluding.

\section{RESULT AND DISCUSSION}

\section{Arabic Teacher Website}

Arabic Teacher is an e-learning-based modern Arabic learning website designed by Dr. Mohamed Mohi El-Din Ahmad, an Arabic language learning expert. He is a lecturer in language development at the University of Brunei Darussalam. He is also an Arabic learning consultant at the Malaysian Institute for National Translation and Islamic Studies and the International Institute for Arabic Language and Islamic Studies in Johor Malaysia.

Arabic Teacher is an e-learning-based modern Arabic learning website explicitly designed for beginners who learn Arabic with a progressive and logical methodology without the need for translation. This website intends to support independent Arabic learning through multimedia's practical use in formal and informal classes. This website is based on a modern programmatic learning system using textbooks and compact discs combined with language skills learning, namely, listening, speaking, reading, and writing.

The Arabic Teacher website has several advantages that other sites don't have. Among them; (1) The website page uses two languages of instruction, namely, Arabic and English; (2) Website pages can be accessed from various devices such as computers, tablets, and cell phones; (3) The website page is equipped with an electronic book and MP3 that can be download so that you can listen to it over and over again without having to reaccess it; (4) Users can easily access this website page without having to create any accounts.

Thus, it is hoped that this website can be used by students, teachers, Arabic language lecturers, and those who wish to learn Arabic.

\section{Main Menu Website of Arabic Teacher}

Arabic Teacher provides several main menus that can be accessed by its users. Among them; main menu for reading, stories (for elementary, intermediate, and advanced), grammar, structure, dictation, songs and games, dictionary for beginners, and questionnaire. The following is a picture of the main menu on the Arabic Teacher website. 


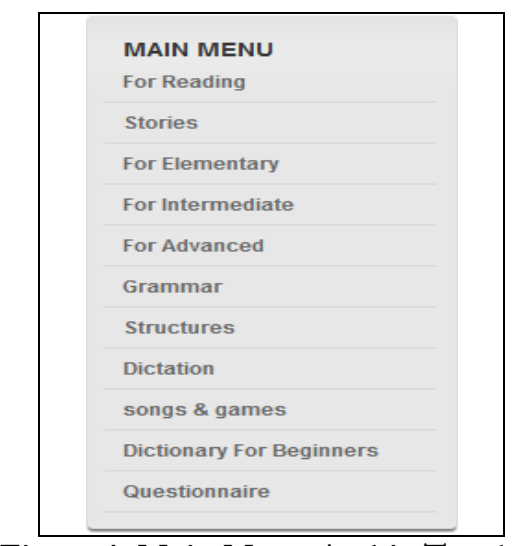

Figure 1: Main Menu Arabic Teacher

\section{For Reading (Al-Qirā'ah)}

Reading is the primary source of learning Arabic for students outside the classroom. Text is the central area of language, contributing to expanding one's knowledge and acquiring new knowledge. In reading two activities, the reader identifies the reading structure and understands the text's contents, both express and implied. This is by the opinion of (Ardiansyah \& Aziz, 2019), asserting that reading skills are not limited to reading fluency correctly and adequately, but how the reader can understand the reading material (fahm al-maqru').

Indraswari (Indraswari, 2014) stated that reading skills are one of the language skills that must be mastered by learners, especially reading comprehension skills. In reading comprehension, learners are required to understand the content of the reading both implicitly and explicitly.

Therefore, in Arabic Teacher, reading material is presented with 18 themes related to akhalq, religion, and culture of the Arab people to provide knowledge for Non-Native Arabic. The following is the theme of the reading presented.

\begin{tabular}{|c|c|c|}
\hline \multicolumn{3}{|c|}{ 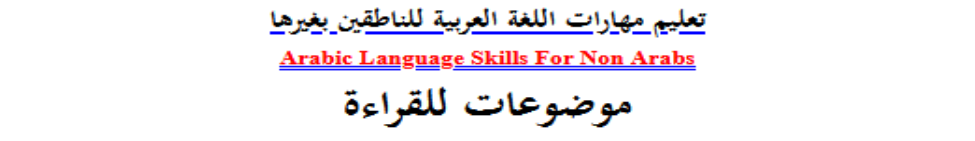 } \\
\hline ألغاز & طرف & حكم_وأمثال \\
\hline آداب طلب العلم & كـيف تذاكر؟ٍ & أدبِ وفصاحة \\
\hline "لا أدري" ... نصف العلم & ثقافة عامة & المعلم الفاضل \\
\hline آداب إسلامية & أرح أعصابِ أطفاللك & "الأم" في أقوال غربية \\
\hline أخحاق إسلامية & امرأة تتكلمِ_بِلقرِآن & الشخصية المسلمة \\
\hline علوم & إسالاميات & دعوة إلى عدم السهري \\
\hline قِواعد إملاليَية & أسالِيب لغوية متقدمة & تدريبات نحوية \\
\hline
\end{tabular}

Figure 2: The Themes In Reading (Al-Qirā'ah) Menu 


\section{For Idiom (A1-Musthalahāt wa al-'Ibārāt)}

The structure referred to here is the Arabic idiom pattern. (Syadiyyah \& Odang, 2019)states that the idiom or (المصططحات والعبارات) is taken from the words which mean expression and agreement. Meanwhile, (Gani \& Arsyad, 2019) defines an idiom is an expression that people agree on to use for specific meanings and on certain occasions.

Phrases in each language have different phrasing and sentence structures. In ذهب إلى، من يتكون Arabic, idioms can be a combination of fi'il and the letter jer such as and others, or also letters with letters like أما

ف; therefore, in this Arabic teaching, learners are known to be part of the idiom form that combines notes with letters in Arabic. The following are Arabic idioms that are often used in reading.

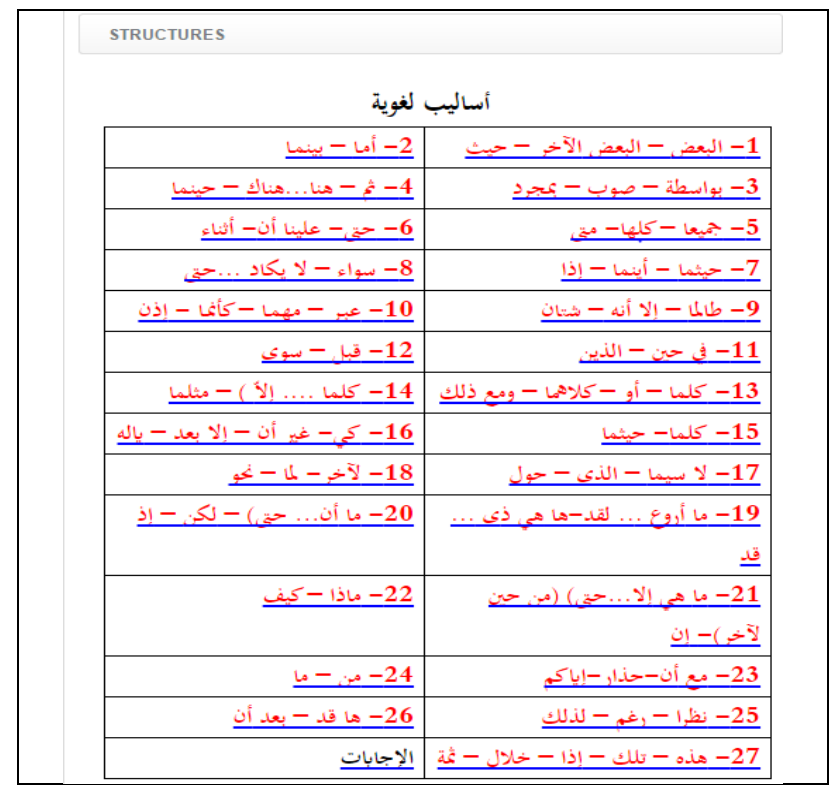

Figure 3: The Themes In Structure (Al-Qawā'id) Menu

\section{For Stories (Qhashas)}

Arabic Teacher provides several stories, song lyrics, and MP3 related themes. The purpose of presenting some of these stories is to improve language skills, especially reading and speaking skills. The story material in Arabic Teacher is classified into three parts based on the level of the learner. The following are the story levels and their themes.

a. Stories For Elementary

This story at the beginner level in Arabic Teacher is presented without a vow. This aims to train learners to get used to reading Arabic stories without harakat. The themes of the info presented are related to learning motivation, morals, and saga. The following are story themes for beginners. 
Ta'lim al-'Arabiyyah : Jurnal Pendidikan Bahasa Arab dan Kebahasaaraban, 4 (2), 2020

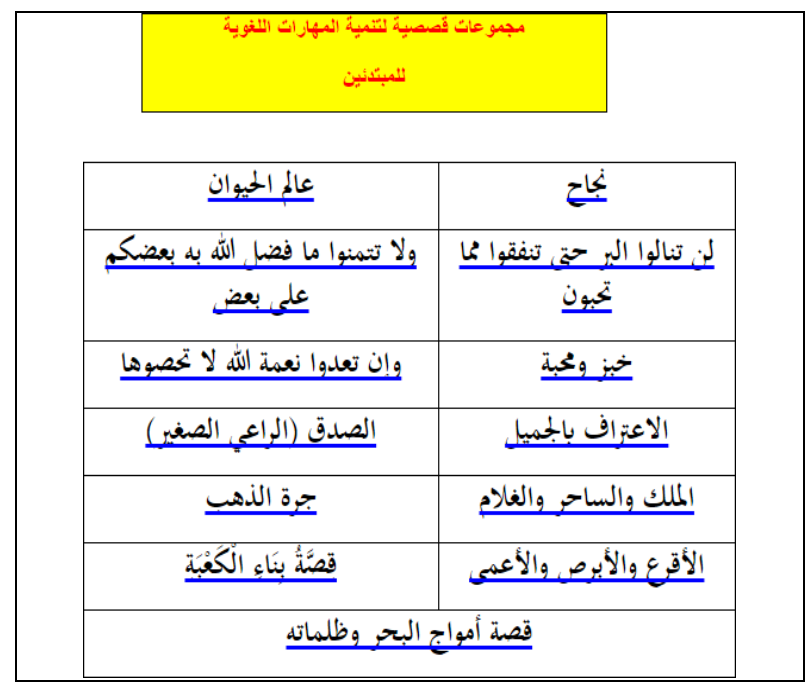

Figure 4: The Themes In Stories (Qhashas) For Elementary Menu

b. Stories For Intermediate

This story at the intermediate level in Arabic Teacher is presented without the vow along with the MP3. This aims to train learners to get used to hearing and reading Arabic stories. Also, at the end of each level, some exercises in understanding the story text's content are provided. The themes of the info presented are related to ancient stories in Arabic. The following are the story themes for the intermediate level.

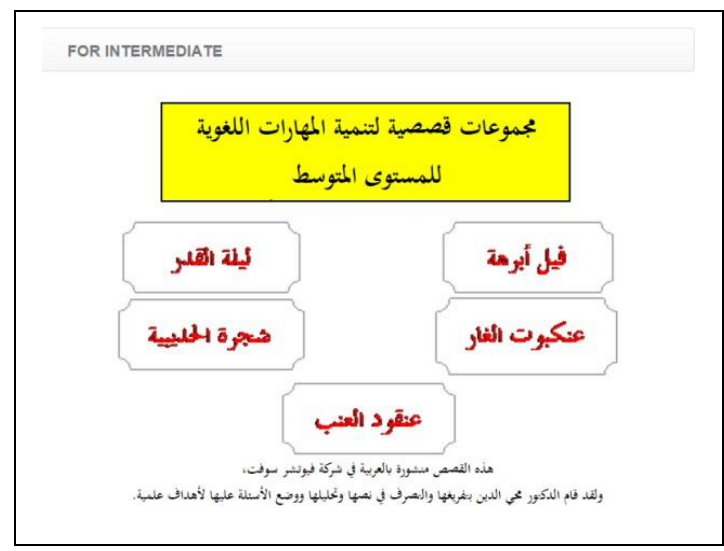

Figure 4: The Themes In Stories (Qhashas) For Intermediate Menu

c. Stories For Advance

This story at an advanced level in Arabic Teacher is presented without the vow along with the MP3. This aims to train learners to get used to hearing and reading Arabic stories. Each end of the story is provided several exercises, including understanding the story text contents, grammar analysis of sentences, and making summaries. The info presented is related to Umar's film, household life, and natural conditions. The following are the story themes for the intermediate level. 


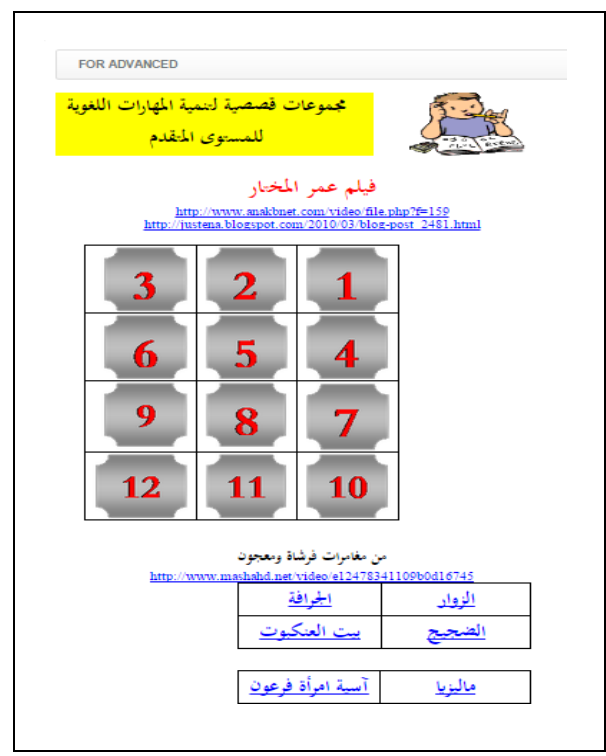

Figure 5: The Themes In Stories (Qhashas) For Advance Menu

\section{For Dictation (Qawā'id al-Imlà)}

What is meant by dictation here are the rules for writing hamzah letters in Arabic sentences. Correspondence in learning Arabic is part of writing skills where Arabic learners must write Arabic sentences correctly in terms of their morphology (word form). Therefore, the main menu dictation presents the writing rules of hamzah qatha' wahsal, mutawasithah, and mutatharifah, complemented by examples and exercises.

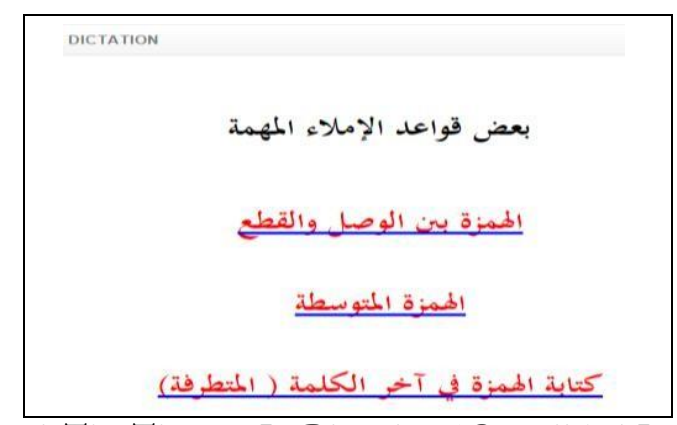

Figure 6: The Themes In Dictation (Qawā'id al-Imlä) Menu

\section{For Grammar (Al-Nahw al-‘Arabi)}

Learning nabwu in Arabic occupies a prominent position. As in the nadzam imritbi, it is stated that nabwu is the fundamental science that must be learned because a speech or writing that is not by the rules of eating nabwu cannot be understood. Rini (Rini, 2019) states that the purpose of nahwu learning is to avoid oral or written language errors and to get used to the fluent language.

For beginner Arabic learners, the meter nabwu presented are applicable nabwu rules such as the arrangement of the number of ismiyah and the number of fi'liyah. Therefore, in the main Arabic Teacher grammar menu, some functional nabwn materials are presented frequently in Arabic. The following is nabwu material for beginner nabwu learners. 


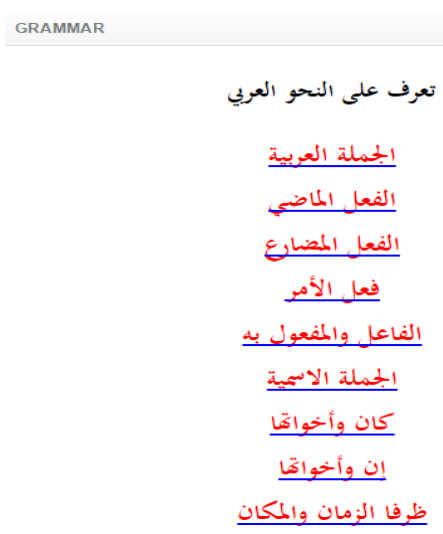

Figure 7: The Themes In Grammar (Al-Nahw al-‘Arabi) Menu

\section{For Games and Songs (Al-Lu'bah wa al-Aghniyah)}

In language learning, games and songs are used as a medium for language learning (Saepurrohman \& Nurhayati, 2019). The use of games in education aims to make learning interactive and exciting, as (Neag, 2019) games are interactive learning media that can make students active and quickly understand the material. Meanwhile, (Hakim, 2018) the results of his research show that songs can motivate learners' learning and make learning engaging, fun, and make the material easier to understand. Therefore, in the Arabic Teacher grammar main menu, several songs and games are presented from level one to level 7 to support learning. Here are examples of song lyrics.

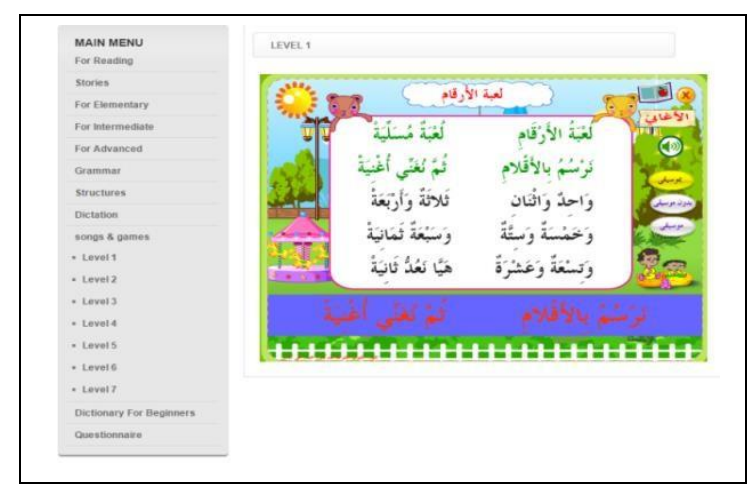

Figure 8: The Themes For Games and Songs (Al-Lu'bah wa al-Aghniyah) Menu

\section{For Dictionary (Al-Qāmūs)}

In learning Arabic, the dictionary serves to find the meaning of new vocabulary in a text or reading. Therefore the principal Arab Teacher presents a thematic dictionary menu with Malay, English, Arabic classified into 24 sub-themes. Here are the subthemes presented. 
Ta'lim al-'Arabiyyah : Jurnal Pendidikan Bahasa Arab dan Kebahasaaraban, 4 (2), 2020

\begin{tabular}{|c|c|c|c|}
\hline 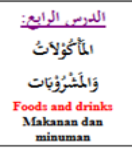 & 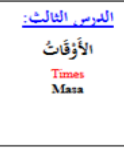 & 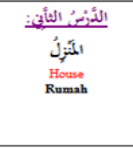 & 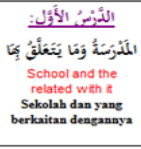 \\
\hline 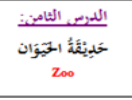 & 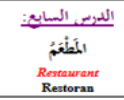 & 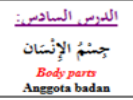 & 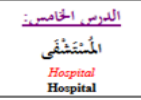 \\
\hline 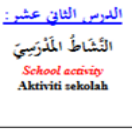 & الدربـ المحاديى & 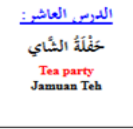 & 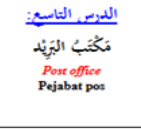 \\
\hline 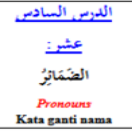 & 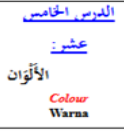 & 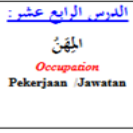 & 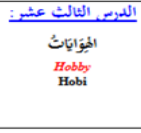 \\
\hline 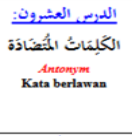 & 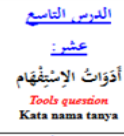 & 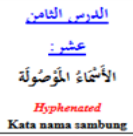 & 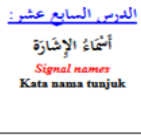 \\
\hline$\frac{2-\operatorname{lil}^{\prime}}{\text { Perbuatan- }}$ & 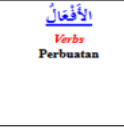 & 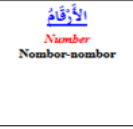 & 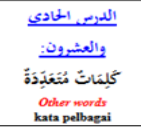 \\
\hline
\end{tabular}

Figure 9: The Themes For Dictionary (Al-Qāmūs) Menu

\section{For Questionnaire}

An assessment sheet is provided for users to assess the website's appearance and its content, suggestions, and comments as material for evaluating improvements. The following is an example of a grading sheet for users.

\begin{tabular}{|c|c|c|c|c|c|}
\hline Questions tenth & res & No & Soalen & $Y_{c}$ & Tidak \\
\hline 1. Do you think that this software is beneficial? & w & Y & Adakah program ini (CD) berfaedah? & & \\
\hline 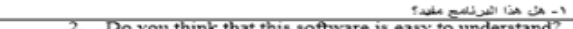 & & & & & \\
\hline 2. Do you think that this software is easy to understand? & & & Adakah program ini (CD) mudah difahami? & & \\
\hline 3. Do you think that this software can improve your is & & & & & \\
\hline 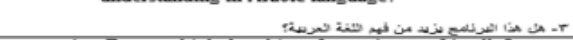 & & & Adakah program ini (CD) dapat meninglatkan kefahaman bahasa & & \\
\hline 4. Do you think that this software is user-friendly? & & & & & \\
\hline 5. Do you think that the exercises provided in this is is & & & Adakah program inf (CD) mudah digunakan? & & \\
\hline $\begin{array}{l}\text { soffware are beneficial and presented in organized } \\
\text { manneer? }\end{array}$ & & & 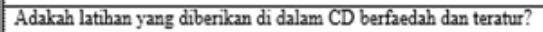 & & \\
\hline 6. Can you understand the narration of this software very wellit? & & & Adakah guara latar yang digunakan di dalam CD jelas \& mudah & & \\
\hline 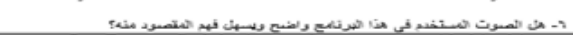 & & & difahami maksudnya? & & \\
\hline $\begin{array}{l}\text { 7. Do you find the interactive games provided in this } \\
\text { software interesting? }\end{array}$ & & & $\begin{array}{l}\text { Adakah permainan interaktif yang disediakan di dalam CD } \\
\text { menyeronokkan? }\end{array}$ & & \\
\hline $\begin{array}{l}\text { 8. Do you find the electronic test helpful and motivate } \\
\text { you to study? }\end{array}$ & & & $\begin{array}{l}\text { Adakah elektronik test membantu dan memberi semangat untuk } \\
\text { belajar semula? }\end{array}$ & & \\
\hline 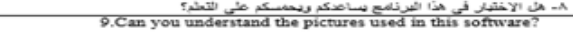 & & & Adakah gambar-gambar yang digunakan di dalam CD sangat & & \\
\hline 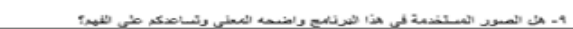 & & & membantu dan mudah difahami? & & \\
\hline
\end{tabular}

Figure 10: For Questionnaire Menu 
Ta'lim al-'Arabiyyah : Jurnal Pendidikan Bahasa Arab dan Kebahasaaraban, 4 (2), 2020

Also, Arabic-teacher is provided an additional main menu located on the front page, like the picture below.

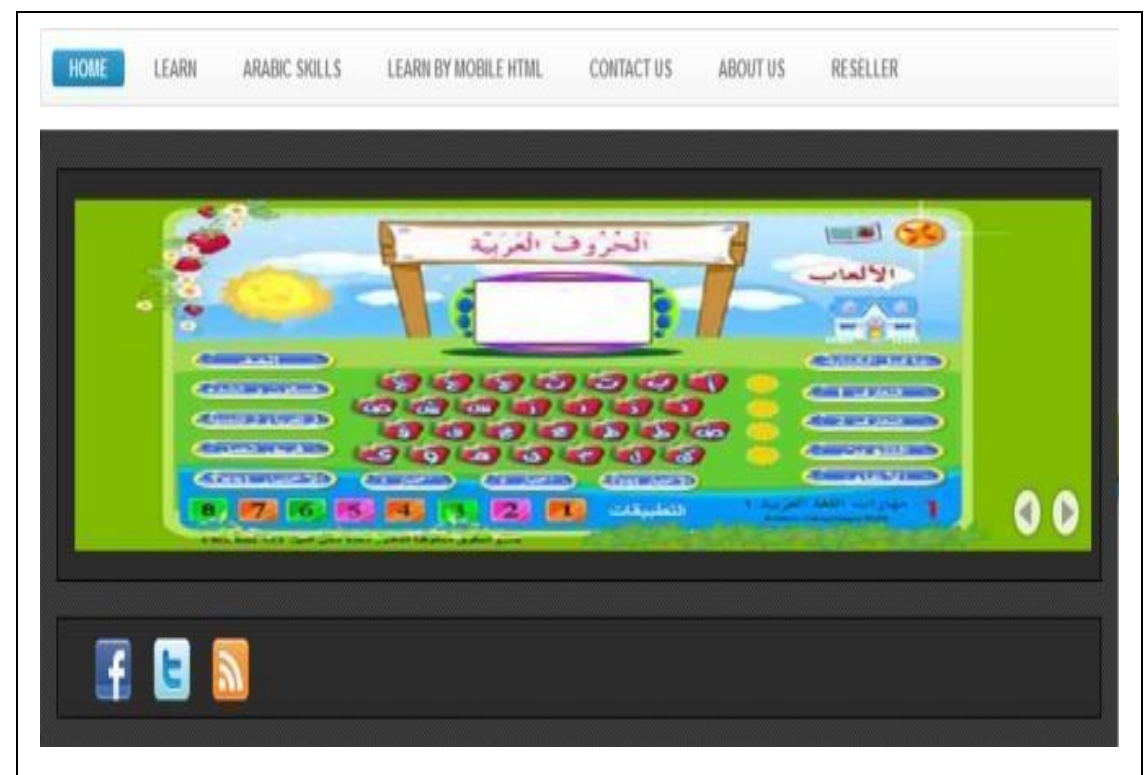

Figure 10: Main Menu Arabic-teacher

\section{Home (Al-Raisah)}

In this section, an overview of Arabic Teacher is explained as modern Arabic learning based on E-learning, and the main menu is presented for learning Arabic. Non-native speakers.

\section{Learn (Al-Ta'allum)}

This section displays two main menus, namely, Help \& video and Introduction. In the help and video section, several videos of vocabulary, conversations, and songs from the E-book are presented, starting from children's level, preparation level, and beginner level. Users can begin learning based on the level of ability and even more if they start from the first level because the material is related to the next level. Meanwhile, the introduction section explains the Website Arabic Teacher in a clear and detailed manner. The following is an image of the main menu in the video section and introduction. 
Ta'lim al-'Arabiyyah : Jurnal Pendidikan Bahasa Arab dan Kebahasaaraban, 4 (2), 2020

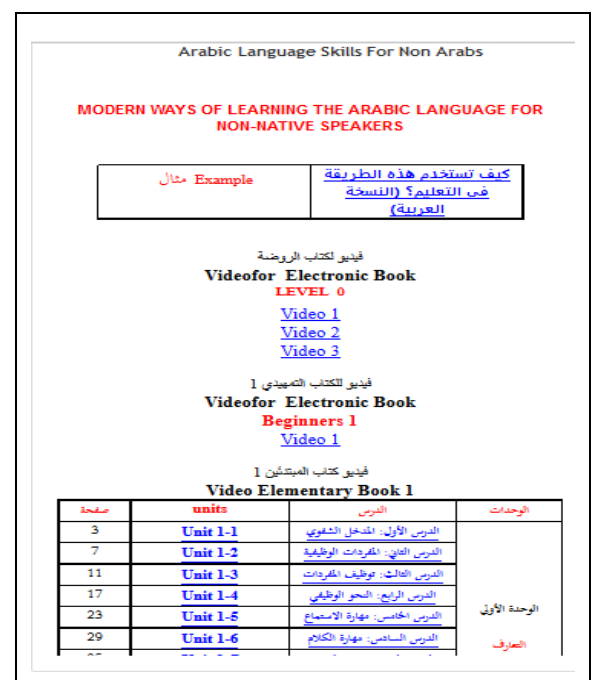

Figure 10: Main Menu Learn (Al-Ta'allum) in Arabic-teacher

\section{Arabic Skill (Mahārah Lughawiyah)}

In this section, some primary material in Arabic is presented, starting from the introduction of Arabic letters, ta'aruf, writing numbers in Arabic, names of objects, various colors, nabwu, short, and others. The following is an example of the material at level 1.

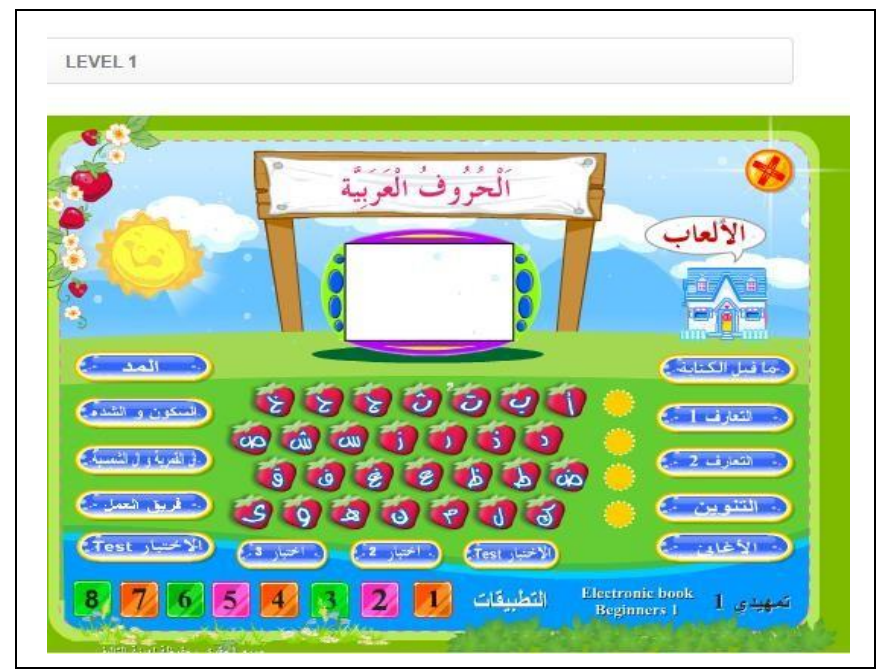

Figure 11: Main Menu For Arabic Skill in Level 1

\section{Contact Us (Ittasil Bina)}

This section contains the identity of the designer of the Arabic Teacher website. 
Ta'lim al-'Arabiyyah : Jurnal Pendidikan Bahasa Arab dan Kebahasaaraban, 4 (2), 2020

\section{Learn By Mobile HTML (Ta'alum bi Istikhdāmil Mobile)}

This section includes an electronic book classified into six parts: beginners 1-3, elementary 1-3, songs, dictionaries, and stories, as shown below.

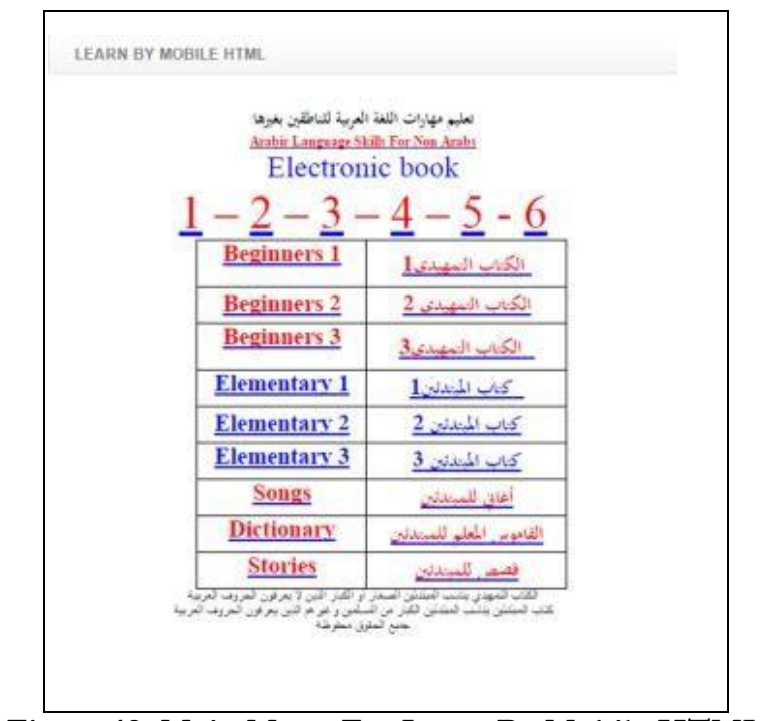

Figure 12: Main Menu For Learn By Mobile HTML

\section{About Us (Man Nahnu)}

This main menu contains the Arabic Teacher designer's CV, e-mail, and a contact person who can be contacted.

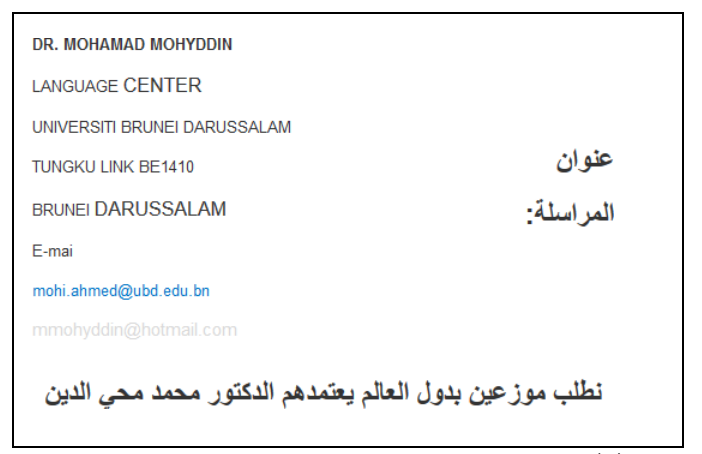

Figure 13: About Us (Man Nahnu) Arabic Teacher 


\section{Reseller (Khidmatul Ba'i)}

This main menu lists the official distributors of books and CD's, as shown below.

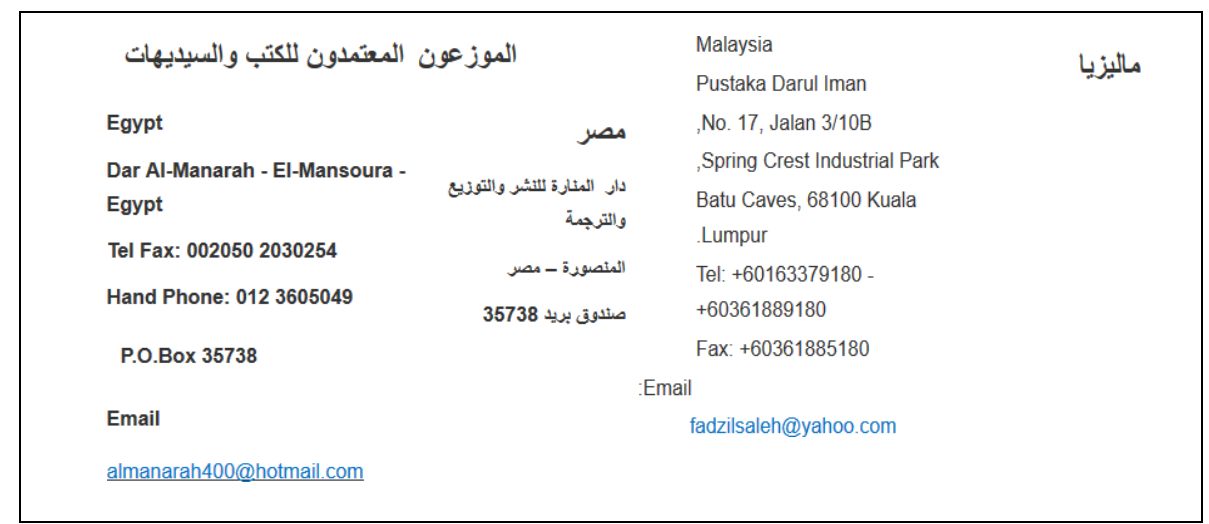

Figure 13: About Us (Man Nahnu) Arabic Teacher

\section{CONCLUSION}

Based on the research results on the Arabic Teacher website as a modern learning model for learning Arabic found on E-learning, it can be concluded as follows: 1) E-Learning Arabic Teacher is a complete website designed as an advanced learning Arabic during the Covid-19 pandemic with a methodology progressively and logically without the need for translation; 2) The Arabic learning approach by using the Arabic teacher E-Learning website is based on the same teaching method programmed, develop internet-based independent learning effectively using a purposeful computer so that learners can learn Arabic in a balanced way read, write, listen, and speak. 3) E-Learning Arabic Teacher provides several main menus including; Arabic languages such as reading, stories (basic, intermediate, advanced), grammar (nabwu), structures (sentence patterns), dictation (imla), songs and games (songs and games), Questionnaires (assessment sheets) accompanied by an electronic book, MP3, and Video.

\section{REFERENCES}

Albantani, A. M. (2018). Optimalisasi Aplikasi Busuu Dalam Pembelajaran Bahasa Arab Mandiri. Arabi: Journal Of Arabic Studies, 3(1), 1. https://doi.org/10.24865/ajas.v3i1.78

Ardiansyah, A. A., \& Aziz, A. A. (2019). Taisīr An-Naḥwi Al Ta’līmī Lī Garḍ Qirāati An-Nușūṣ Al-'Arabiyyah Gair Al-Masykūlah. Lisanudhad, 6(2), 86. https://doi.org/10.21111/lisanudhad.v6i2.3478

Aziz Khoiri, A., \& Fatkhu Romadhon, I. (2017). Arabic Teacher: Pembelajaran Modern Bahasa Arab Berbasis E-Learning Bagi Non-Native Speaker. Konferensi Nasional Babasa Arab Iii (Kreativitas Dan Inovasi Dalam Pembelajaran Bahasa Arab Di Indonesia), 289-299.

Azzuhri, M. (2015). Metode Dan Media Pembelajaran Bahasa Arab Berbasis Internet Di Era Teknologi Informasi. Insania: Jurnal Pemikiran Alternatif Kependidikan, 
Ta'lim al-'Arabiyyah : Jurnal Pendidikan Bahasa Arab dan Kebahasaaraban, 4 (2), 2020

14(3), 348-445. https://doi.org/10.24090/insania.v14i3.360

Baharudin, H., \& Ismail, Z. (2014). Vocabulary Learning Strategies And Arabic Vocabulary Size Among Pre-University Students In Malaysia. International Education Studies. https://doi.org/10.5539/ies.v7n13p219

Chang, C. L., \& Fang, M. (2020). E-Learning And Online Instructions Of Higher Education During The 2019 Novel Coronavirus Diseases (Covid-19) Epidemic. Journal Of Physics: Conference Series. https://doi.org/10.1088/17426596/1574/1/012166

Febriani, S. R., \& Anasruddin, A. (2020). Technology For Four Skills Arabic In The Era Emergency Of Covid-19 In Indonesia. Ta'lim Al-'Arabiyyah: Jurnal Pendidikan Bahasa Arab \& Kebahasaaraban. https://doi.org/10.15575/jpba.v4i1.8221

Gani, S., \& Arsyad, B. (2019). Kajian Teoritis Struktur Internal Bahasa (Fonologi, Morfologi, Sintaksis, Dan Semantik). 'A Jamiy: Jurnal Babasa Dan Sastra Arab. https://doi.org/10.31314/ajamiy.7.1.1-20.2018

Haffar, N., Maraoui, M., Aljawarneh, S., Bouhorma, M., Alnuaimi, A. A., \& Hawashin, B. (2017). Pedagogical Indexed Arabic Text In Cloud E-Learning System. International Journal of Cloud Applications And Computing. https://doi.org/10.4018/ijcac.2017010102

Hakim, M. L. (2018). Pemanfaatan Media Pembelajaran Game Interaktif Dalam Pembelajaran Kosakata Bahasa Arab. Arabi: Journal Of Arabic Studies. https://doi.org/10.24865/ajas.v2i2.56

Ilmiani, A. M., Ahmadi, A., Rahman, N. F., \& Rahmah, Y. (2020). Multimedia Interaktif Untuk Mengatasi Problematika Pembelajaran Bahasa Arab. Al-Ta'rib: Jurnal Ilmiah Program Studi Pendidikan Bahasa Arab Iain Palangka Raya. https://doi.org/10.23971/altarib.v8i1.1902

Indraswari, R. (2014). Penerapan Paduan Pembelajaran Problem Based Learning (Pbl) Dan Kooperatif Type Student Teams Achievement Division (Stad) Untuk Meningkatkan Keterampilan Membaca Bahasa Arab. Lisanul' Arab: Journal Of Arabic Learning And Teaching, 3(1), 24-30. https://doi.org/10.15294/la.v3i1.4135

Iswanto, R. (2017). Pembelajaran Bahasa Arab Dengan Pemanfaatan Teknologi. Arabiyatuna: Jurnal Bahasa Arab. https://doi.org/10.29240/jba.v1i2.286

Kurnia, N., Darmawan, D., \& Maskur, M. (2018). Efektivitas Pemanfaatan Multimedia Pembelajaran Berbantuan Ispring Dalam Meningkatkan Motivasi Dan Hasil Belajar Pada Mata Pelajaran Bahasa Arab. Teknologi Pembelajaran.

Martono Kurniawan, T., \& Nurhayati Oky, D. (2014). Implementation Of AndroidBased Mobile Learning Application As A Flexible Learning Media. International Journal Of Computer Science Issues.

Maryeni, L., Siregar, S. N., \& Roza, Y. (2020). Development Of Computer-Based Learning Media Using Mind Map For Learning Mathematics In Topics Of Rectangle And Triangle At Secondary School. 2019(July 2019), 73-84.

Neag, A. (2019). Board Games As Interview Tools: Creating A Safe Space For Unaccompanied Refugee Children. Media And Communication. https://doi.org/10.17645/mac.v7i2.1817 
Pimada, L. H., \& Muhammad Afif Amrulloh. (2020). Penerapan Media Elektronik Pada Pembelajaran Bahasa Arab. Labjah Arabiyab: Jurnal Babasa Arab Dan Pendidikan Bahasa Arab, 1(2), 120-128. https://doi.org/10.35316/lahjah.v1i2.819

Purwanto, A., \& Hanief, S. (2016). Multimedia Pembelajaran Bahasa Indonesia Untuk Mahasiswa Berbasis Animasi. Jurnal Sistem Dan Informatika.

Rafiee, M., \& Abbasian-Naghneh, S. (2019). E-Learning: Development Of A Model To Assess The Acceptance And Readiness Of Technology Among Language Learners. Computer Assisted Language Learning. https://doi.org/10.1080/09588221.2019.1640255

Rini, R. (2019). Ushul Al-Nahwi Al-Arabi: Kajian Tentang Landasan Ilmu Nahwu. Arabiyatuna: Jurnal Bahasa Arab. https://doi.org/10.29240/jba.v3i1.773

Ritonga, M., Nazir, A., Wahyuni, S., Muhammadiyah, U., Barat, S., Dan, I., Di, K., Padang, K., Jurnal, A., \& Bahasa, P. (2016). Pembelajaran Bahasa Arab Berbasis Teknologi Informasi Dan Komunikasi Di Kota Padang. Pendidikan Bahasa Arab, $3(1), 1-12$.

Saepudin. (2015). E-Learning Dalam Pembelajaran Mata Kuliah Perencanaan Desain Pembelajaran Bahasa Arab Pada Mahasiswa Pba Stain Parepare. Al-Ishlah.

Saepurrohman, A., \& Nurhayati, S. L. (2019). Istikhdām Uslūb Al Ghinā Fī Ta'līm Al Mufradāt Al 'Arabiyyah Li Tarqiyati Qudrah Al Talāmīdz 'Alā Alhiwār Al 'Arabī. Ta'lim Al-'Arabiyyab: Jurnal Pendidikan Bahasa Arab \& Kebahasaaraban, 3(2), 175193. https://doi.org/10.15575/jpba.v3i2.7715

Sahrir, M. S., \& Alias, N. A. (2012). A Design And Development Approach To Researching Online Arabic Vocabulary Games Learning In Iium. Procedia - Social And Behavioral Sciences. https://doi.org/10.1016/J.Sbspro.2012.11.339

Silahuddin, S., \& Azhari, A. (2019). Inovasi Media Pembelajaran Bahasa Arab Berbasis E-Learning. Circuit: Jumal Ilmiah Pendidikan Teknik Elektro, 3(1), 40. https://doi.org/10.22373/crc.v3i1.4426

Syadiyyah, S. S., \& Odang, O. (2019). Istikhdām Wasīlah Bithāqah Tashnīf Al Kalimāt Fī Ta'līm Al Tarkīb Litarqiyati Qudrah Al Talāmīdz 'Alā Al Al Insyā Al Muwajjah. Ta'lim Al-'Arabiyyah: Jurnal Pendidikan Bahasa Arab \& Kebahasaaraban, 3(2), 103-119. https://doi.org/10.15575/jpba.v3i2.7600

Yasmar, R. (2017). Multimedia Interaktif Pembelajaran Bahasa Arab Untuk Siswa Madrasah Aliyah. Arabiyatuna: Jumal Babasa Arab. https://doi.org/10.29240/jba.v1i2.325 